\title{
Effect of temperature on laboratory growth, reproduction and life span of Octopus bimaculoides
}

\author{
J.W. Forsythe and R. T. Hanlon
}

The Marine Biomedical Institute, The University of Texas Medical Branch, 200 University Boulevard, Galveston, Texas 77550-2772, USA

\begin{abstract}
Laboratory culture of 40 Octopus bimaculoides from April 1982 to August 1983 through the full life cycle at $18^{\circ} \mathrm{C}$ vs $23^{\circ} \mathrm{C}$ provided information on the growth, reproductive biology and life span of this California littoral octopus. At $18^{\circ} \mathrm{C}$, the cephalopods grew from a hatchling size of $0.07 \mathrm{~g}$ to a mean of $619 \mathrm{~g}$ in $404 \mathrm{~d}$; the largest individual was $872 \mathrm{~g}$. Octopuses cultured at $23^{\circ} \mathrm{C}$ reached their highest mean weight of $597 \mathrm{~g}$ in $370 \mathrm{~d}$; the largest individual grown at this temperature was $848 \mathrm{~g}$ after $404 \mathrm{~d}$. Growth data revealed a two-phase growth pattern: a 5 mo exponential phase followed by a slower logarithmic (power function) phase until spawning. At 5 mo octopuses grown at $23^{\circ} \mathrm{C}$ were over three times larger than their $18^{\circ} \mathrm{C}$ siblings. However, beyond $6.5 \mathrm{mo}$, growth rates were no higher at $23^{\circ} \mathrm{C}$ than at $18^{\circ} \mathrm{C}$. At $13.5 \mathrm{mo}$, the mean weight of the $18^{\circ} \mathrm{C}$ group surpassed that of the $23^{\circ} \mathrm{C}$ group. The slope of the length/weight $(\mathrm{L} / \mathrm{W})$ relationship was significantly different for the two temperature regimes, with the $23^{\circ} \mathrm{C}$ octopuses weighing $18 \%$ less than their $18^{\circ} \mathrm{C}$ siblings at a mantle length of $100 \mathrm{~mm}$. Females weighed more than males at any given mantle length. Males grew slightly larger and matured before females. The $\mathrm{L} / \mathrm{W}$ relationship indicated isometric body growth throughout the life cycle. Higher temperature accelerated all aspects of reproductive biology and shortened life span by as much as $20 \%$ (from approximately 16 to $13 \mathrm{mo}$ ). $O$. bimaculoides has one of the longest life cycles among species with large eggs and benthic hatchlings. Extrapolations to field growth are made, and the possible effects of temperature anomalies such as El Niño are discussed.
\end{abstract}

\section{Introduction}

Cephalopods are important predators in marine ecosystems, where they compete with vertebrate fishes; this competition has led to many forms of convergence (Packard 1972). However, cephalopods differ dramatically from fishes with respect to their high rate of growth, semelparous reproductive strategy and comparatively short life spans (see Boyle 1983, 1987). Various studies have described the effects of temperature on cephalopod growth, reproduction or life span (Van Heukelem 1979), but no study before the present report has analyzed the effect of temperature on these three aspects of octopus biology simultaneously throughout the full life cycle. The laboratory data reported herein (the first for this species) are based upon observations of two groups of Octopus bimaculoides cultured from eggs to sexual maturity and egg-laying in the laboratory under two temperature regimes.

Octopus bimaculoides is a common inter- and sub-tidal species along the southern California coast, with a known range extending from approximately Santa Barbara, California south to San Quintin, Mexico on the upper Baja peninsula. There is little published information on the biology of this species. Hochberg and Fields (1980) and Forsythe and Hanlon (1988) have reviewed the literature, and the latter authors have made laboratory and field observations on aspects of the behavior and reproductive biology of the species. The present study arose as a part of our ongoing research in evaluating various large-egged octopus species as potential laboratory-culture candidates for supplying biomedical research needs (Hanlon and Forsythe 1985).

The specific objective of this study was to evaluate the influence of temperature on growth, age at reproduction and resultant life span to see if it might be used as a tool in timing reproduction and expanding the temporal availability of eggs. By accelerating growth and reproduction of some brood-stock individuals and retarding that of others, it might be possible to achieve egg-laying throughout the year. Additionally, this type of information is useful to fisheries biologists and ecologists studying aspects of cephalopod biology in nature, where temperature can in- 
fluence distributions and life-history patterns. The shortterm elevation in temperature during an El Niño event is a specific example of how laboratory data can be useful in understanding the impact of such a phenomenon on rapidly growing, short-life-span predators such as Octopus spp.

\section{Materials and methods}

The culture project was conducted from April 1982 to August 1983 in the Division of Biology and Marine Resources laboratory of The Marine Biomedical Institute in Galveston, Texas. All culture work was carried out in two closed, recirculating seawater systems, each consisting of a circular 2000-liter capacity water-conditioning tank above which were supported shallow culture-trays. This system has been described in detail by Hanlon and Forsythe (1985). In the main system (SYST 1), a $1 \mathrm{hp}$ seawater chilling unit was used to maintain water temperature at approximately $18^{\circ} \mathrm{C}$. The second culture system (SYST 2) was maintained at warmer ambient laboratory temperatures (mean $23^{\circ} \mathrm{C}$ ). Artificial sea water (Instant Ocean brand) was used exclusively throughout this study. Temperature and salinity were recorded daily and levels of ammonia $\left(\mathrm{NH}_{4}-\mathrm{N}\right)$, nitrite $\left(\mathrm{NO}_{2}-\mathrm{N}\right)$ and nitrate $\left(\mathrm{NO}_{3}-\right.$ $\mathrm{N})$ were measured weekly. Salinity was maintained between 34 and $36 \%$. Periodically, 50 to $70 \%$ water changes were made when inorganic nitrogen levels increased. When $\mathrm{pH}$ levels fell below 7.75, additions of sodium bicarbonate increased $\mathrm{pH}$. Trace elements (HW Marine Mix) were added regularly to prevent their possible depletion between water changes. The culture systems received overhead fluorescent lighting and natural, indirect sunlight from large adjacent windows. The light cycle was approximately the same as that outdoors, since the fluorescent lights were only on from 08.00 to $17.00 \mathrm{hrs}$.

Eggs were laid by a field-collected (near Los Angeles, California) female Octopus bimaculoides being held for physiological studies in San Antonio, Texas. The eggs were maintained at $17^{\circ} \mathrm{C}$ in a 400 -liter closed system using artificial sea water for the first three weeks, and were then removed from the mother and transported to Galveston in sealed plastic bags containing sea water and pure oxygen. Eggs were placed in SYST 1 and maintained at $18^{\circ} \mathrm{C}$ for the remainder of their development. Hatching occurred over an $8 \mathrm{~d}$ period from mid- to late June 1982 . The modal hatching day was considered to be Day 1 for the study. $O$. bimaculoides was cultured under two temperature regimes, beginning at hatching. The main population (initiated with 177 hatchlings) was kept in SYST 1 after hatching and cultured at $18^{\circ} \mathrm{C}$. To evaluate the tolerance of this species to higher temperatures, a second smaller group ( 45 hatchlings) was moved to SYST 2 and cultured at temperatures near $23{ }^{\circ} \mathrm{C}$. During the first $6 \mathrm{mo}$, isolated individual octopuses were measured and weighed regularly. Thereafter (Day 218), most or all of the culture population was measured. The octopuses were narcotized first in a $1.5 \%$ solution of ethyl alcohol in sea water, and then measured for mantle length (ML) and wet weight (WW) after the mantle cavity had been drained of sea water. At this time, they were also inspected visually for signs of hectocotylus development. Octopuses revived in fresh sea water without assistance within 2 to $3 \mathrm{~min}$.

Linear regression analyses of the growth data were performed (Forsythe 1984). For each chronological series of length and weight measurements, a line of best fit to the data was calculated mathematically by a least-squares linear regression, and an equation describing the growth data was generated. The mean length or weight of the entire sample group at each measuring period was used in these determinations. The linear regressions were performed using standard computer curve-fitting programs. The following equations were tested to generate lines of best fit to the growth data:

$$
\begin{aligned}
& \text { linear, } y=a+b x \\
& \text { exponential, } y=a e^{b x} \text {; } \\
& \text { power, } y=a x^{b} \\
& \log , y=a+b \ln x
\end{aligned}
$$

where $y=$ length or weight and $x=$ age in days; $a=$ the $y$ intercept, $b=$ the slope and $e=$ the natural logarithm of 2 . The square of the correlation coefficient $\left(r^{2}\right)$ was calculated for each linear regression and used to determine which equation best described a given set of data. To avoid confusion, it should be noted that, traditionally, growth described by the power equation is referred to as logarithmic growth (Brody 1945). That is what it shall be taken to mean in this paper and not growth described by the log equation as listed above.

Growth rates were determined using the instantaneous coefficient of growth, $G$, calculated from the equation:

$$
G=\frac{\log _{\mathrm{e}} Y_{2}-\log _{\mathrm{e}} Y_{1}}{t_{2}-t_{1}}
$$

where $Y_{2}=$ final length or weight, $Y_{1}=$ initial length or weight, $t_{2}=$ age in days at $Y_{2}$, and $t_{1}=$ age in days at $Y_{1}$ (Brown 1957, Wells and Wells 1970, Forsythe and Van Heukelem 1987). The instantaneous relative growth rate (percent increase in body length or body weight per day; $\% /$ day) was calculated by multiplying $G$ by 100 . Multiplying any given length $(L)$ or weight $(W)$ by $G$ gave growth rates in $\mathrm{mm}$ per day (for $G \times L$ ) or grams per day (for $G \times W$ ). Doubling time (DBL), i.e., the time required for an individual to double in weight, was calculated by dividing the natural $\log$ of 2 by $G$. Where necessary, data were compared using Student's $t$-tests after variance-ratio tests (Zar 1974) had been performed to assure means came from normally distributed populations. An analysis of covariance (Zar 1974) was used to test for differences in slopes and elevations of linear forms of calculated growth curves. This was done using $\log _{\mathrm{e}}$-transformed data: $x$ and $\log _{\mathrm{e}} y$ for exponential functions, and $\log _{\mathrm{e}} x$ and $\log _{\mathrm{e}} y$ for power functions. 


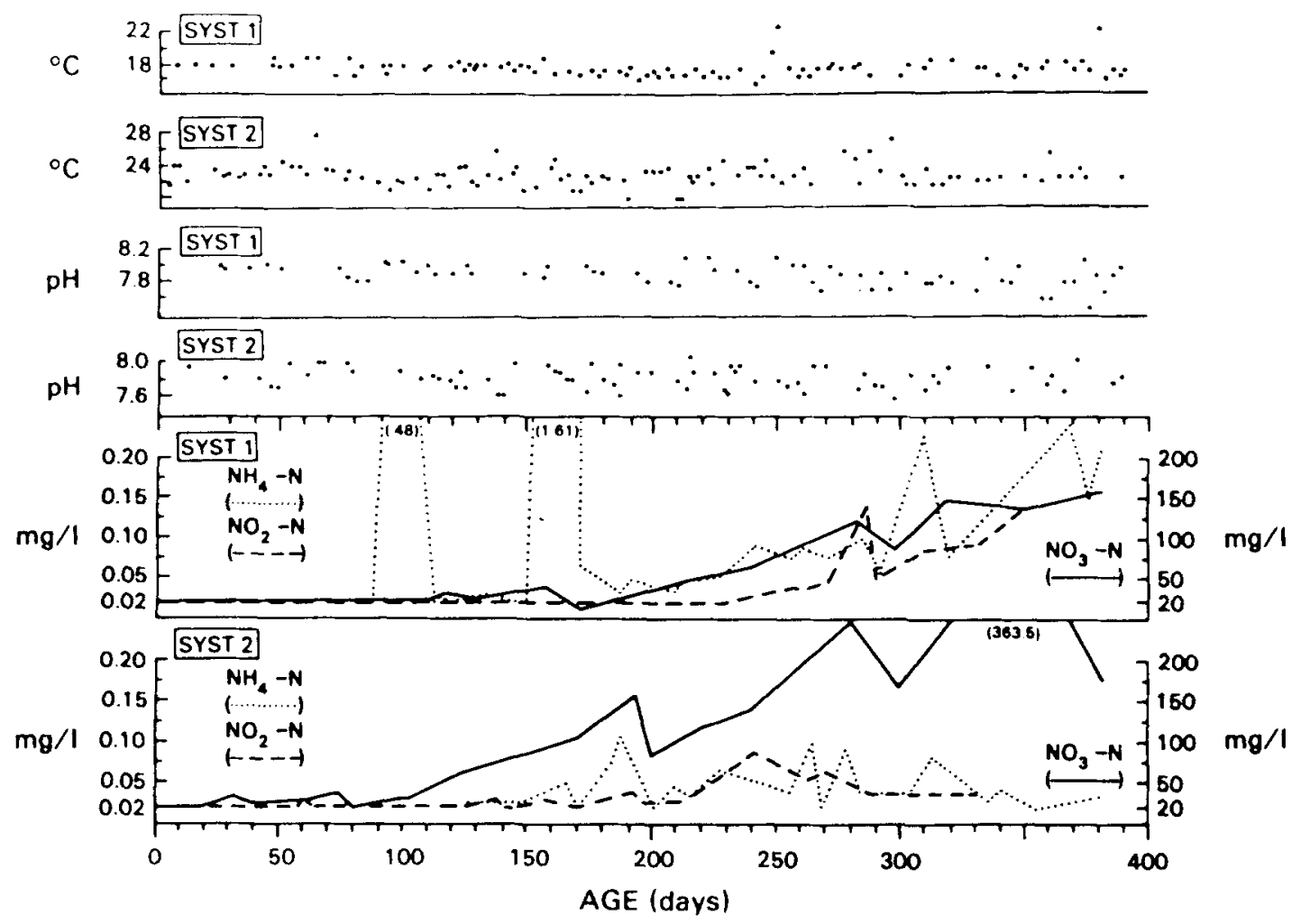

Fig. 1. Synopsis of water-chemistry data for closed systems used in this study

\section{Results}

Forty Octopus bimaculoides were cultured through the life cycle from hatching to sexual maturity and egg-laying. The population was maintained in culture until 18 August 1983, when all surviving octopuses were lost during a $72 \mathrm{~h}$ power failure after Hurricane Alicia.

\section{Water quality}

Since all research was conducted in closed, recirculating seawater systems, synopses of the water-chemistry data during the study are presented in Fig. 1. In SYST 1, monthly mean temperatures ranged from $17.2^{\circ}$ to $18.6^{\circ} \mathrm{C}$, with an overall mean of $17.96^{\circ} \mathrm{C}$. The minimum and maximum temperatures were $16.5^{\circ}$ and $23.0^{\circ} \mathrm{C}$, respectively; on only four days were temperatures above $19^{\circ} \mathrm{C}$. In SYST 2, temperatures ranged from $19.0^{\circ}$ to $28.0^{\circ} \mathrm{C}$, with monthly means ranging from $20.1^{\circ}$ to $24.4^{\circ} \mathrm{C}$. Temperatures were above $25^{\circ} \mathrm{C}$ on only $11 \mathrm{~d}$. The overall mean temperature was $22.98^{\circ} \mathrm{C}$. Temperature fluctuations were much greater in this system, since it varied with ambient laboratory temperatures. The measured levels of $\mathrm{pH}$, ammonia, nitrite and nitrate (Fig. 1) were within acceptable ranges for octopuses (Hanlon and Forsythe 1985) and had no observable deleterious effects on behavior, feeding, growth or survival.
Growth

The wet weight data are summarized in Table 1 and the mantle length data in Table 2. The calculated growth equations are listed in Table 3.

\section{Growth in weight}

Octopus bimaculoides grew from an approximate hatching size of $0.07 \mathrm{~g}$ to a mean of $619 \mathrm{~g}$ in 404 days at $18^{\circ} \mathrm{C}$. Growth was exponential in form from hatching until Day 156 (Eq. 1 in Table 3), with a mean relative growth rate of $3.56 \%$ of body weight per day (\%/day). The octopuses doubled in weight approximately every $22 \mathrm{~d}$ for a total of seven doublings during this period. Growth was slower after Day 156, becoming logarithmic in form (Forsythe 1984), as described by Eq. (2) in Table 3. Table 1 shows a decrease in mean wet weight at Day 218. Beginning on this day, most or all of the population was measured rather than a sub-sample. Growth rates decreased from nearly $3 \% \mathrm{~d}^{-1}$ at Day 170 to less than $1 \% \mathrm{~d}^{-1}$ at Day 404 The mean doubling time increased to about $54 \mathrm{~d}$, yielding 4.5 doublings over this period.

The break in the growth phases at Day 156 coincided with the first appearance of the hectocotylus (a modification of the third right arm of males that is used in transferring spermatophores). It is noteworthy that the 
Table 1. Octopus bimaculoides. Growth in weight at $18^{\circ} \mathrm{C}$ and $23^{\circ} \mathrm{C}$. Growth rates calculated from difference between consecutive measurements. Dash indicates no growth rate calculated

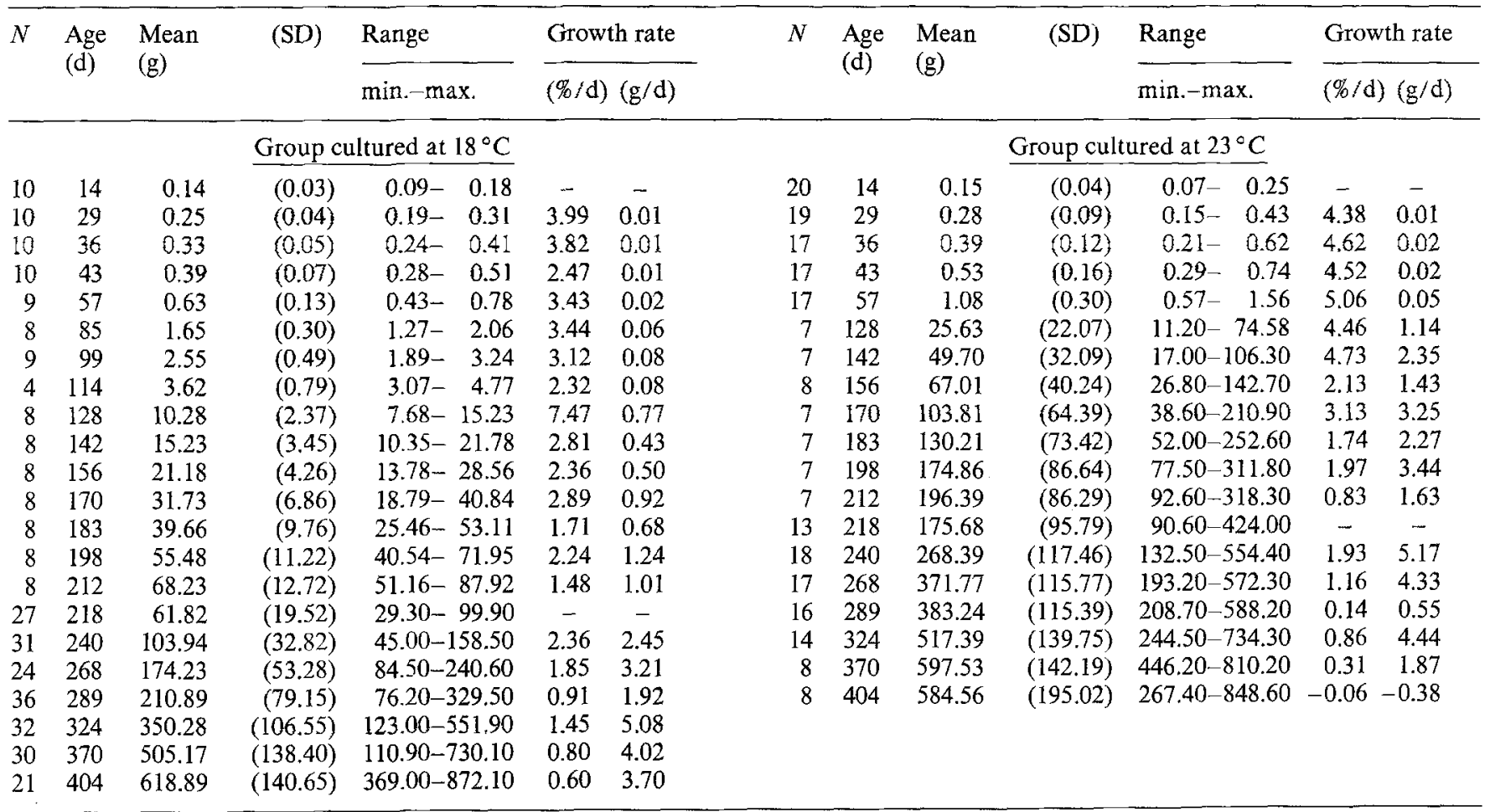

Table 2. Octopus bimaculoides. Growth in mantle length

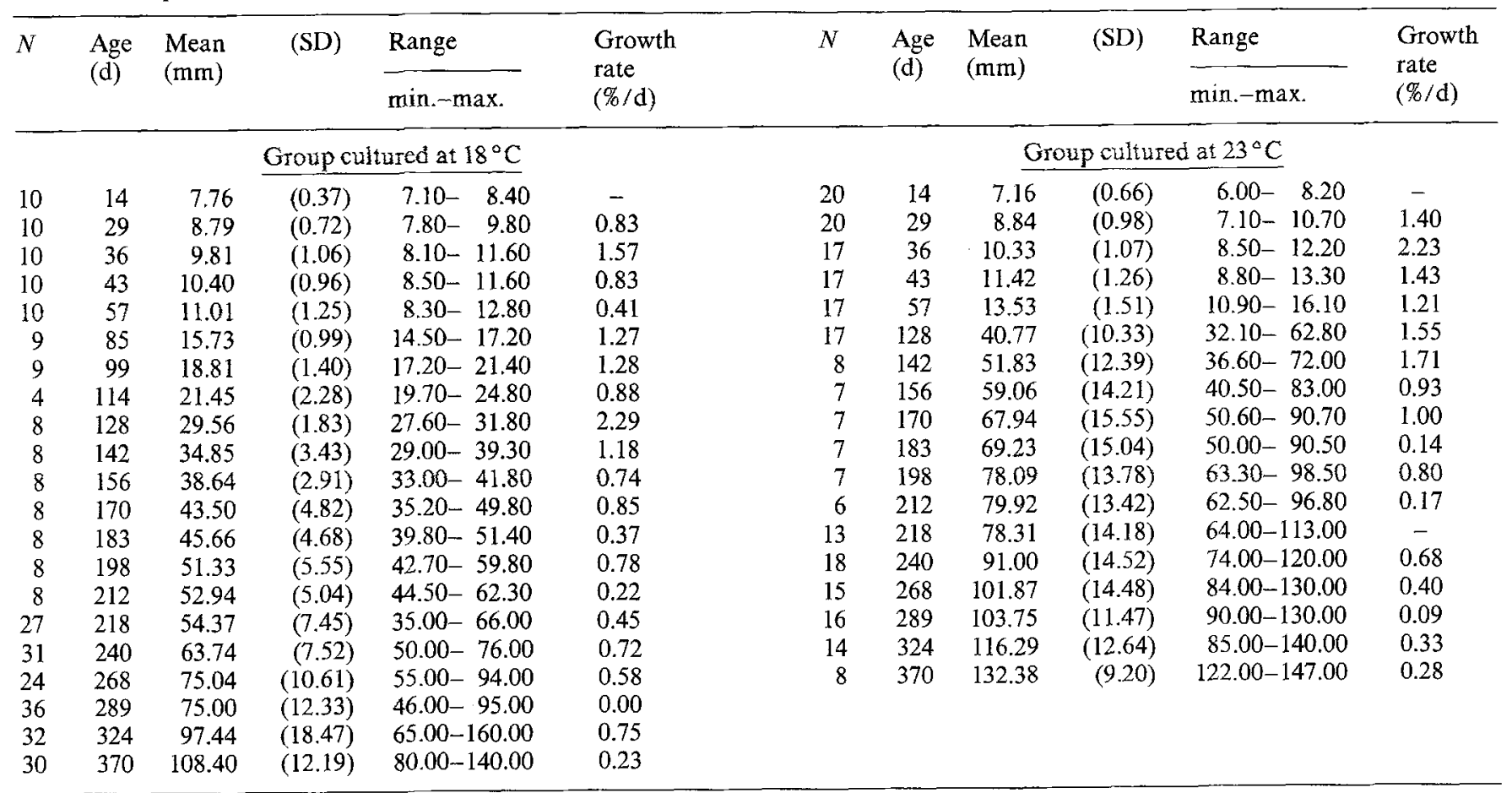

female data up to Day 198 included some males that were not yet identifiable; however, beyond Day 198 the sexes could be differentiated clearly. The equations for the male and female data are given in Table 3 (Eqs. 3 and 4, respectively). Males and females were similar in weight up to Day 218. Thereafter, the mean weight of males was consistently higher than that of females. This is illustrated in Fig. 3. Over this time period the mean instantaneous growth rate for males was $1.8 \% \mathrm{~d}^{-1}$, compared to $1.5 \% \mathrm{~d}^{-1}$ for females. A Student's $t$-test analysis revealed no statisti- 
Table 3. Octopus bimaculoides. Growth equations for live wet weight, mantle length and length/weight relationship

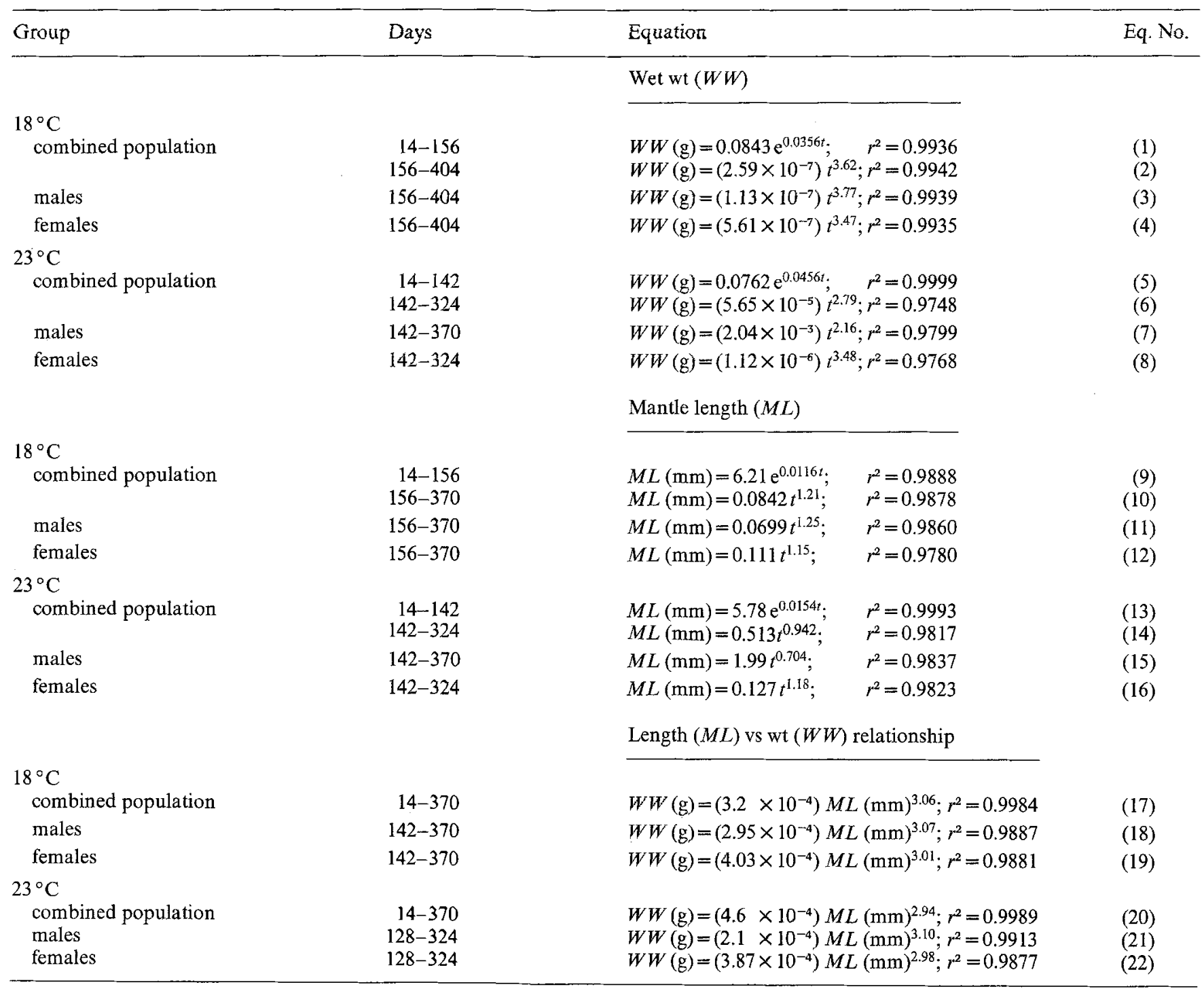

cally significant differences in mean wet weights of males and females at any measurement period. However, there was a significant difference $(p<0.05)$ in the slopes of simple linear regressions of the log-transformed data of males and females. Thus, the slope value of Eq. (3) for male growth is significantly higher than that of Eq. (4) for females, and indicative of a slightly higher growth rate among males.

The weight data for the warm-water population are also listed in Table 1. Analysis revealed the same pattern of growth over slightly different time periods. The faster exponential growth phase lasted until Day 142 (Eq. 5) with an average growth rate of $4.5 \% \mathrm{~d}^{-1}$. The doubling time was $15 \mathrm{~d}$, producing 9.5 doublings in weight. The slower logarithmic phase lasted from Days 142 to 324 (Eq, 6). Differences in male and female growth resulted in poor curve fits to combined data beyond Day 324. Males continued to grow logarithmically until at least Day 370 , with growth leveling off at Day 404. Eq. (7) for male growth was calculated through Day 370 . Females es- sentially stopped growing after Day 324 (Fig. 3), and this cessation of the growth phase concided with egg-laying in this group betwen Days 315 and 370 . The equation for female growth (Eq. 8) was therefore only calculated through Day 324. Again, as in the main population, males had consistently higher mean weights than females. Despite this finding, analysis showed that females were growing slightly faster than males. The mean instantaneous growth rate for females from Days 128 to 324 was $2.1 \%$ $\mathrm{d}^{-1}$, while males had a mean of $1.5 \% \mathrm{~d}^{-1}$. In addition, the higher slope of the female growth equation (Eq. 8) was significantly different $(p<0.001)$ from that of the males (Eq. 7). Apparently, the male octopuses were larger than female octopuses at the end of the exponential growth phase. This size difference was large enough to allow the mean male weights to stay larger than the mean female weights, although the more rapidly growing females were continually lessening this difference.

The strong influence of temperature on the growth of Octopus bimaculoides is seen clearly by comparing the 


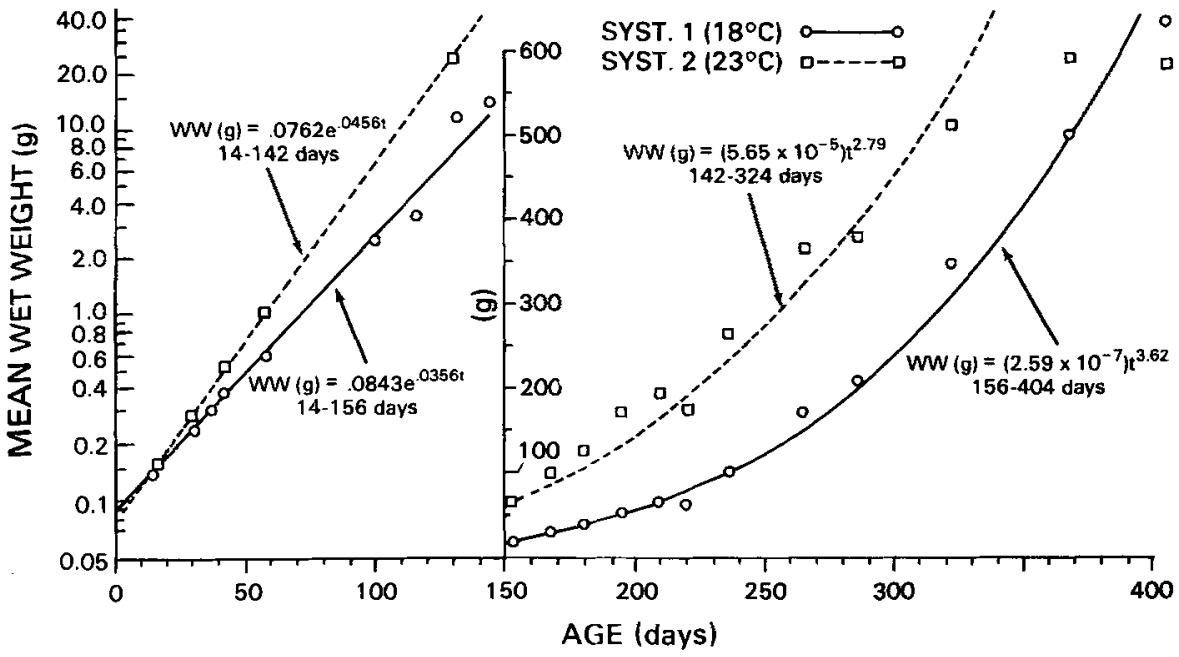

Fig. 2. Octopus bimaculoides. Growth curves for individuals cultured through life cycle under two temperature regimes

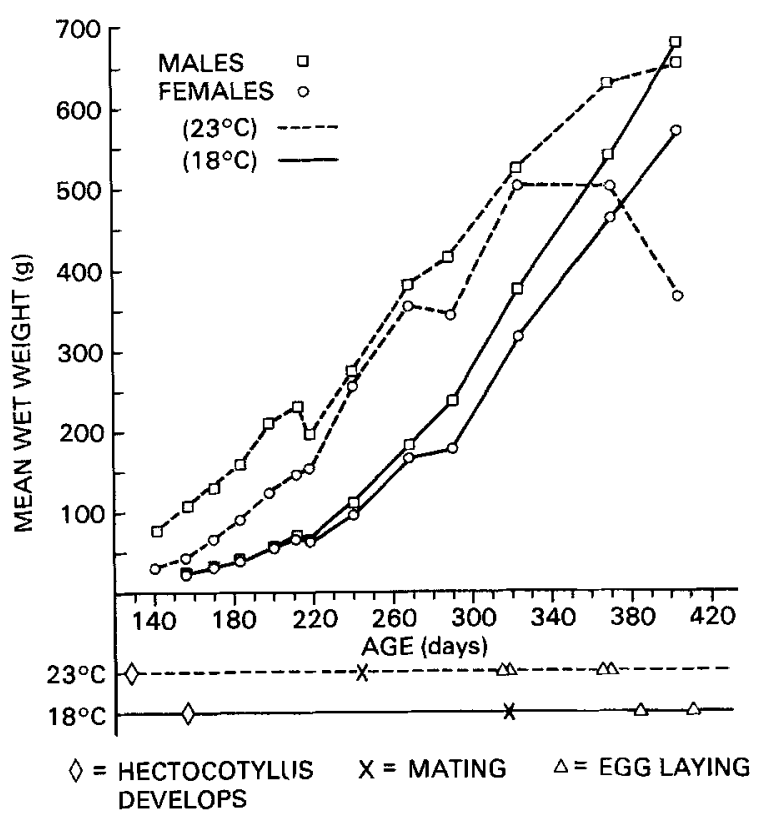

Fig. 3. Octopus bimaculoides. Comparative growth of males and females at $18^{\circ}$ and $23^{\circ} \mathrm{C}$. Major events in reproductive life cycle are plotted for each temperature beneath age axis

growth data of the main population $\left(18^{\circ} \mathrm{C}\right)$ to the data of the warm-water group $\left(23^{\circ} \mathrm{C}\right)$ in Table 1 and Figs. 2 and 3. Over the course of the exponential growth phase, the octopuses at $23^{\circ} \mathrm{C}$ grew on the average $1 \% \mathrm{~d}^{-1}$ faster than the octopuses at $18^{\circ} \mathrm{C}\left(4.5 \mathrm{vs} 3.5 \% \mathrm{~d}^{-1}\right)$. This difference in growth rate resulted in a three-fold difference in mean size by Day 142 ( 49.7 vs $15 \mathrm{~g}$ ). Over this period, the warm-water juveniles doubled in weight 9.5 times compared to 6.5 times for their cold-water siblings. This three-fold difference in weight continued up to Day 198, after which it gradually declined until Day 404, when the cold-water group had a higher mean weight for the first time. The largest individual cultured $(872 \mathrm{~g})$ was a male from the cold-water population. Comparing the growth curves for the two groups in Fig. 2, it is clear that the slope of Eq. (5) (warm-water juveniles) is higher than that of Eq. (1) (coldwater juveniles); this difference is highly significant ( $p<$ $0.001)$. For the curves describing the periods of logarithmic growth in Fig. 2, the slope of Eq. (2) is higher than that of Eq. (6) and this difference is highly significant $(p<0.001)$. Closer examination of the data showed that growth of the warm-water group did not begin to slow until after Day 198, and only then did the cold-water group have consistently higher relative growth rates. The slowed growth of the warm-water group was essentially attributable to the males in the group. Comparing the slope of Eq. (7) to Eqs. (8), (3) and (4), it can be seen that the warm-water males had the lowest slope value. The warm-water females, on the other hand, had essentially the same slope as their cold-water counterparts, with the statistical analysis showing no significant differences in the slopes.

\section{Growth in length}

Mantle length is a long-standing measure in cephalopod biology, even though it is not as useful as weight. The mantle length data in Table 2 were analyzed in the same fashion as the wet weight data. The growth equations for the mantle length data are also given in Table 3. Growth in length paralleled the relationships described for growth in weight. The growth equations had lower $r^{2}$ values than those of the weight data. This is due to the greater variability encountered with length measurements of the soft-bodied octopuses.

\section{Length vs weight relationship}

The length vs weight $(\mathrm{L} / \mathrm{W})$ relationship was examined by comparing concurrent wet weight and mantle length (ML) data. Table 3 presents the equations describing this relationship (Eqs. 17-22). Although growth in weight occurred in two phases over the life cycle, the $\mathrm{L} / \mathrm{W}$ relation 
maintained nearly identical slope values throughout the entire life cycle and, therefore, single equations were used to describe the combined group data from Days 14 to 370 (last-day ML measurements were taken). Eq. (17) describes the L/W relationship for the main culture population and is depicted graphically in Fig. 4. Eqs. (18) and (19) describe the male and female data, respectively. An analysis of covariance showed no statistically significant difference in the slopes or elevations of the male and female curves. Using the equations to calculate wet weights at given mantle lengths, it can be seen that females weigh more than males of the same mantle length. For example, at $100 \mathrm{~mm} \mathrm{ML}$, the equations estimate the weight of females at $422 \mathrm{~g}$, the weight of males at $407 \mathrm{~g}$.

Eq. (20) describes the L/W relationship for the warmwater population. The male and female L/W data for the warm-water group were curve-fit to Day 324 , since this produced a better fit than to Day 370 . There was no statistically significant difference in the slopes of Eqs. (21) and (22). Again, females weighed more than males at the same ML. At $100 \mathrm{~mm} \mathrm{ML}$, females are predicted to weigh $353 \mathrm{~g}$ and males $333 \mathrm{~g}$.

The slopes of the L/W relationship for the cold-water and warm-water population (Eqs. 17 and 20, respectively) were significantly different $(p<0.002)$. The slope of the $\mathrm{L} / \mathrm{W}$ relationship was not found to be statistically different in comparisons between the two temperatures for just the exponential growth phase, logarithmic growth phase, males or females. At a mature size of $100 \mathrm{~mm} \mathrm{ML}$, the octopuses cultured at $23^{\circ} \mathrm{C}$ weighed an average of $18 \%$ less than their siblings cultured at $18^{\circ} \mathrm{C}(348 \mathrm{~g}$ vs $422 \mathrm{~g}$ ). This same magnitude of weight difference was seen when comparing males or females at the two temperatures. These analyses suggest that the longer it takes an individual to reach a given ML, the more the octopus will weigh. Males reached any given mantle length before females, but females weighed more than males of the same mantle length. Likewise, the warm-water group grew faster than the cold-water group, but the latter group weighed more than the former at the same mantle length.

The slope of the $\mathrm{L} / \mathrm{W}$ relationship lies typically between 2.5 and 4.0 (Brody 1945, Brown, 1957). A slope of 3.0 indicates that weight (or volume) is increasing as the cube of length (or linear size), resulting in isometric body growth and constant body proportions (Gould 1966, Ricker 1979). Slopes significantly greater than or less than 3.0 are indicative of allometric growth, which produces changes in body proportions over the life cycle. Octopus bimaculoides seems to display isometric body growth through its life cycle, since Eqs. (17) and (20) vary only slightly above and below a slope value of 3.0 .

\section{Reproductive biology}

\section{Sexual maturation}

The earliest sign of sexual maturation was the formation of the hectocotylus on the third right arm of males. In the

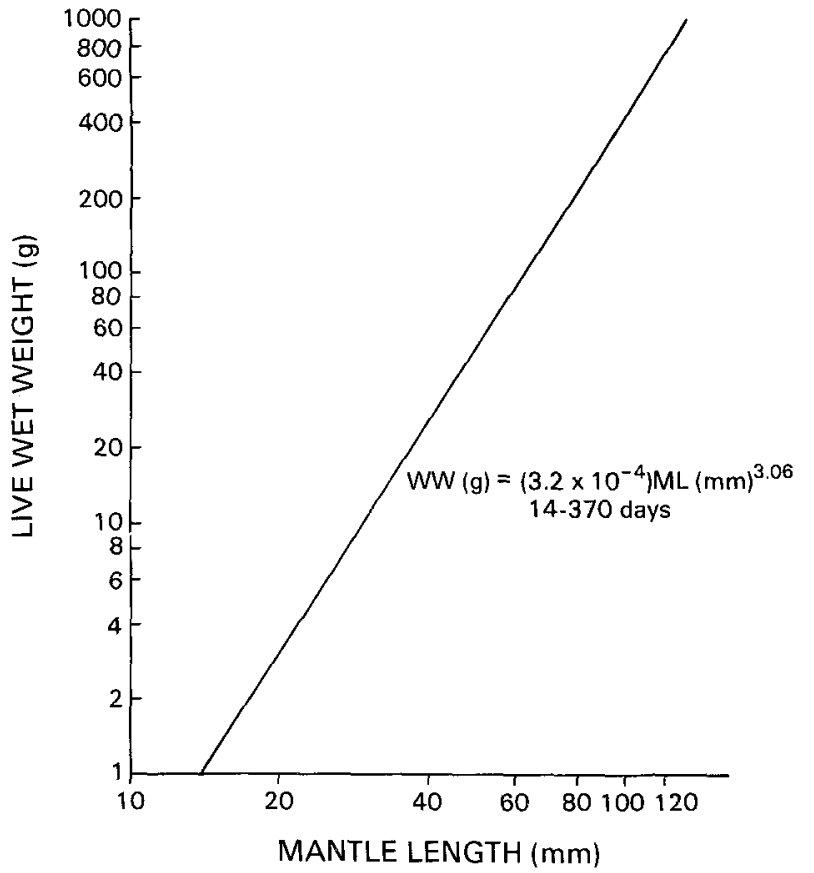

Fig. 4. Octopus bimaculoides. Length versus weight relationship for main-culture population grown at $18^{\circ} \mathrm{C}$

main culture population (SYST 1) the first males with an identifiable hectocotylus were found on Day 156. All males could be identified by approximately Day 200 . The appearance of the hectocotylus was seen approximately one month earlier (Day 128) in the smaller culture group being grown at higher temperatures (SYST 2), with all males identifiable by Day 170 (Fig. 3).

Among females, the only external visible sign of sexual maturation was the rapid enlargement of the ovary in the distal end of the mantle. This enlargement did not become evident until the month prior to egg-laying; during this period the ovary increased from less than a tenth of the internal mantle space to almost one-third to one-half the mantle space.

\section{Mating and egg-laying}

Matings were observed on Day 317 in the main culture population and almost 2.5 mo earlier (Day 241) in the warm-water group (Fig. 3). These first matings followed first hectocotylus formation in the two groups by approximately 5.4 and $3.8 \mathrm{mo}$, respectively.

Egg-laying followed the initiation of mating behavior by two to four months in both populations. Only two broods of eggs were laid in the main culture population before it was lost. These broods were laid on Days 383 and 409 , but perished before completing development. The 12 females in this group that died after the hurricane were preserved, and their ovaries examined for degree of maturation. Four females had ripe ovaries, with one apparently dying the day she would have begun egg- 
laying since there were eggs at the opening of each oviduct. The eight remaining females were still immature. Four broods of eggs were laid in the warm-water population on Days 315, 316, 365 and 369. Of the four broods, two were fertile, one infertile and one brood was destroyed when the mother was killed by another larger female. A fifth female had died on Day 284 when her ovary literally burst open with fully mature eggs.

The duration of egg development varied dramatically with temperature. The brood of eggs from which the octopuses in this study hatched required $82 \mathrm{~d}$ to develop at a mean temperature of $17.8^{\circ} \mathrm{C}$. In contrast, the two fertile broods in the warm-water population required only 46 and $51 \mathrm{~d}$ at $23.4^{\circ}$ and $22.5^{\circ} \mathrm{C}$, respectively.

\section{Discussion}

\section{Temperature}

Elevated temperature caused a dramatic increase in growth rate during the exponential growth phase of Octopus bimaculoides. This effect diminished as the octopuses entered the slower logarithmic growth phase of their life cycle. Beyond Day 200 , the higher temperature $\left(23^{\circ} \mathrm{C}\right)$ produced no increase in relative growth rate over that at $18^{\circ} \mathrm{C}$. Van Heukelem (1976) reared O. maya from hatching at $20^{\circ}$ and $30^{\circ} \mathrm{C}$. After $60 \mathrm{~d}$, the $20^{\circ} \mathrm{C}$ octopuses had grown in weight at a mean rate of $3.8 \% \mathrm{~d}^{-1}$ vs $7.5 \% \mathrm{~d}^{-1}$ for the $30^{\circ} \mathrm{C}$ individuals. He also found the length of the exponential growth phase was much shorter at $30^{\circ} \mathrm{C}$ $(75 \mathrm{~d})$ than at $20^{\circ} \mathrm{C}(165 \mathrm{~d})$. Once the $30^{\circ} \mathrm{C}$ individuals ended their exponential growth phase, growth rates declined gradually until, at about Day 200, their growth rates dropped below those of their $20^{\circ} \mathrm{C}$ siblings. Pascual (1978) found that the growth rates of young cuttlefish (Sepia officinalis) between one and three months of age were nearly twice as high at $22^{\circ} \mathrm{C}\left(5.1 \% \mathrm{~d}^{-1}\right)$ than at $16^{\circ} \mathrm{C}$ $\left(2.7 \% \mathrm{~d}^{-1}\right)$.
All large-egged octopus species reared through the life cycle in the laboratory have displayed the same two-phase growth pattern characterized by an early, rapid, exponential growth phase followed by a somewhat slower, logarithmic (power-function) growth phase to the onset of spawning (Forsythe 1984, Forsythe and Van Heukelem 1987). Some comparisons of growth-phase duration and overall instantaneous relative growth rate for each phase are made in Table 4. Octopus bimaculoides and $O$. briareus show very similar growth patterns, having an extended exponential growth phase compared to the other species. $O$. briareus weighs approximately $55 \mathrm{~g}\left(17^{\circ}\right.$ to $\left.25^{\circ} \mathrm{C}\right)$ at the end of its exponential phase, while $O$.bimaculoides weighs $45 \mathrm{~g}\left(23^{\circ} \mathrm{C}\right)$. O. bimaculoides has a longer logarithmic growth phase, but growth rates are similar.

This same relationship has been noted in other cephalopod species (Forsythe and Van Heukelem 1987) where, within a species, the slower-growing sex weighs more at a given ML than its counterpart. A surprising finding is that, for a given length, the cold-water Octopus bimaculoides weighed more than those reared at warmer temperatures. This emphasizes the potential errors of estimating biomass from length measurements, a custom followed by many invertebrate larval biologists. Overall, temperature seemed to have an impact on the $\mathrm{L} / \mathrm{W}$ relationship in this species, but it did not produce individuals visibly different in morphology.

The existing L/W data for octopuses was reviewed by Forsythe (1984) and Forsythe and Van Heukelem (1987). The L/W relationship for Octopus bimaculoides is most similar to that reported for O. vulgaris (Guerra 1979) and Eledone moschata (Boletzky 1974). For example, O. bimaculoides $\left(18^{\circ} \mathrm{C}\right)$ and $O$. vulgaris weigh 0.36 and $0.42 \mathrm{~g}$ at $10 \mathrm{~mm} \mathrm{ML}$, and 421 and $410 \mathrm{~g}$ at $100 \mathrm{~mm} \mathrm{ML}$, respectively. The exponent of the $\mathrm{L} / \mathrm{W}$ relationship is near 3.0 for all three species, indicating isometric growth throughout the life cycle. Not all octopuses grow isometrically. $O$. briareus, $O$. joubini and $O$. digueti display allometric growth during part or all of the life cycle, indicating changes in body proportions throughout the life cycle.

Table 4. Octopus spp. Comparison of growth-phase duration and growth rate for five species. (Where necessary, growth rate was calculated from data in cited papers)

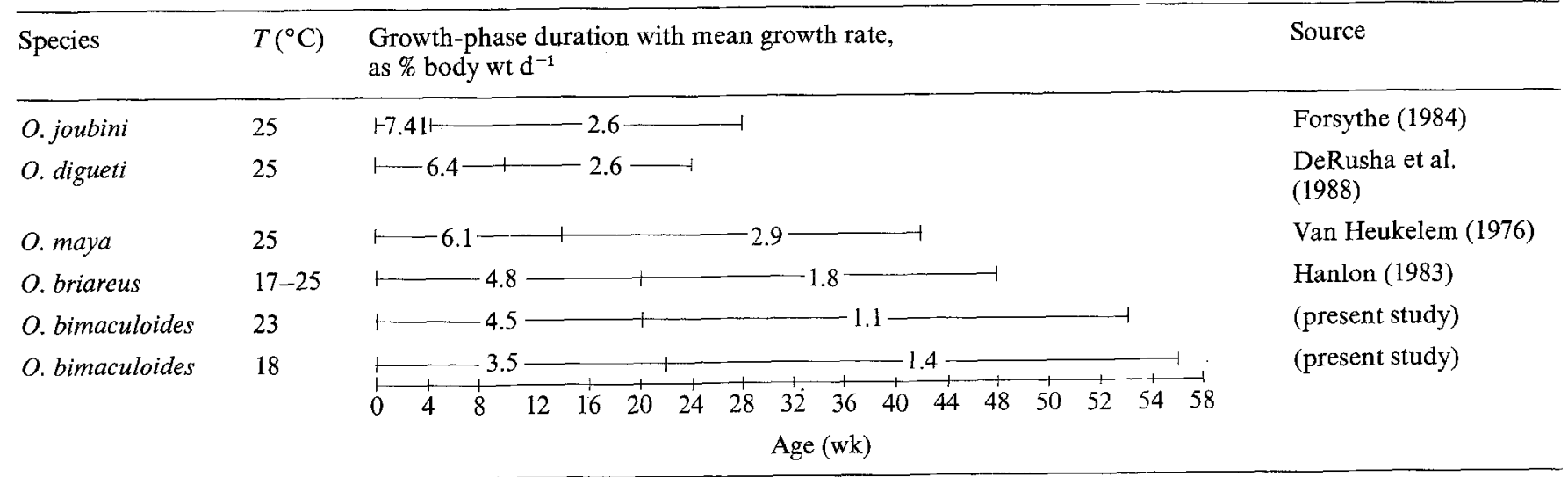




\section{Reproductive biology}

Van Heukelem (1979) reviewed data indicating that light, temperature and food influence sexual maturation in cephalopods. It is significant, in the present study, that temperature alone was shown to have a strong effect on all aspects of reproductive biology and eventual life span (Fig. 3). In Octopus bimaculoides an elevation in temperature of $5 \mathrm{C}^{\circ}$ over the entire life span accelerated hectocotylus formation by one month, mating and egg-laying by two months, and duration of egg development by one month. It may have shortened the life cycle by as much as three to four months. As discussed previously, temperature had no effect on growth rate beyond Day 200, yet its effects on reproductive biology over this same period are clear. Richard (1966) was able to show similar effects of temperature on the sexual maturation of Sepia officinalis. Cuttlefish reared at $20^{\circ} \mathrm{C}$ reached full sexual maturity in seven months, while siblings at $15^{\circ} \mathrm{C}$ were showing only the first signs of gonad development and individuals at $10^{\circ} \mathrm{C}$ were showing no gonadal development at all. Clearly, temperature must be considered in estimating life spans of cephalopod species, particularly when temperature varies over the geographic range.

\section{Life span}

Octopus bimaculoides appears to be fairly long-lived for an octopus. At $18^{\circ} \mathrm{C}$, females began spawning at $12.5 \mathrm{mo}$; however, the majority of females were still immature at 14 mo. The additional three months required for egg brooding gives a total life span of at least 15 to $17 \mathrm{mo}$. At $23^{\circ} \mathrm{C}$, females spawned at 10 to $12 \mathrm{mo}$, giving a complete life span with egg brooding of 12 to 14 mo. Males appear to live at least as long as females. Among large-egged octopods, only Eledone moschata in the Mediterranean Sea is known to have as long a life span as $O$. bimaculoides (Mangold 1983); it ranges from 12 to $24 \mathrm{mo}$, depending upon seasonal temperature. The life spans of most other large-egged species range from 6 to 12 mo (Boyle 1983). Species with planktonic hatchlings typically have slightly longer life spans (12 to $18 \mathrm{mo}$ ) due to their 1 to $3 \mathrm{mo}$ planktonic phase (Boyle 1983). Life-span estimates have been reported for three small-egged octopus species found on the Pacific coast of the USA. Hartwick (1983) predicted a life span range of 3 to $5 \mathrm{yr}$ for the giant Pacific octopus $O$. dofleini, and Dorsey (1976) estimated 2 to $3 \mathrm{yr}$ for $O$. rubescens. Both estimates were for populations in the Pacific northwest (Washington, British Columbia) that have a low seasonal temperature range of $7^{\circ}$ to $15^{\circ} \mathrm{C}$.

Octopus bimaculatus is a sibling species of O.bimaculoides (Pickford and McConnaughey 1949) and its ecology has been studied by Ambrose (e.g. 1984, 1986, 1988) off Catalina Island in California. It is of similar size (at Catalina Island), appearance and habitat, except that it hatches as a "paralarva" (Young and Harman 1988) that spends several weeks to months in the plankton before

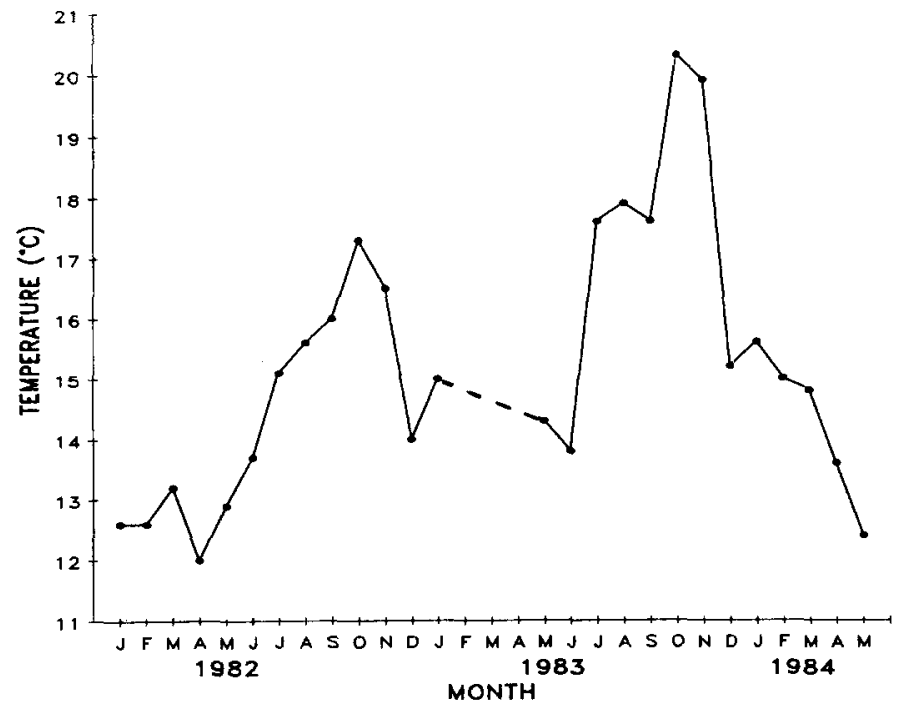

Fig. 5. Mean sea-water temperatures for first week of each month, taken from daily temperature records at University of California at Santa Barbara Marine Laboratory. Dashed portion of line indicates no data available from February through April of 1983

settling. Based upon size-frequency, abundance and reproduction data from field samples, Ambrose (1988) proposed two possible models of its life cycle: an "alternating generation" model in which octopuses that hatch early enough in spring grow sufficiently fast to spawn 13 mo after settling, and an "alternating years" model in which all octopuses take $2 \mathrm{yr}$ to spawn. Although Ambrose's field data tend to support the "alternating years" model, our laboratory growth data indicate that, even at $16^{\circ} \mathrm{C}, O . b i$ maculatus could grow fast enough to spawn at 13 mo postsettlement. A major unknown factor with $O$. bimaculatus is the duration of the planktonic phase; settlement occurs throughout the year (Ambrose 1988).

However, Octopus bimaculoides with its direct development and very large, benthic adult-like hatchlings has a more predictable life cycle. Although few field data are available, we can estimate the following. In May 1984 we found many females brooding eggs at various stages of development (freshly-laid to posthatching) off Santa Barbara, the northernmost part of its range. With May to July temperatures about $14^{\circ}$ to $17^{\circ} \mathrm{C}$ (Figs. 5), eggs would hatch about mid-summer, the time of highest temperature $\left(17^{\circ}\right.$ to $19^{\circ} \mathrm{C}$ in most years). Even with the fast exponential growth in the first 3 to 5 mo posthatching, when temperatures are highest, it seems unlikely from our laboratory growth data at $18^{\circ} \mathrm{C}$ that $O$. bimaculoides could be large enough to spawn the following summer, since interim temperatures off Santa Barbara are in the range of $12^{\circ}$ to $15^{\circ} \mathrm{C}$. This scenario better fits the "alternating years" model of Ambrose (1988), in which O. bimaculoides would spawn after two years.

Conversely, in the southern range of Octopus bimaculoides, it is possible that the populations could spawn at one year of age ("alternating generation" model). Temperatures at Catalina Island (Ambrose 1988; his Fig. 2) are several degrees warmer throughout the year, and tempera- 
tures nearshore can be warmer farther south in coastal areas between San Diego and San Quintin, Mexico. The surprising growth, vigor and early reproduction of this "cold-water species" cultured at a warm $23^{\circ} \mathrm{C}$ in our laboratory may be a reflection of its need to survive in the fluctuating environment of the intertidal zone. Experimentation in progress shows that O.bimaculoides can also grow well in reduced salinity $(25 \%)$, a trait very rare among cephalopods, which are generally stenohaline (the squid Lolliguncula brevis is the only documented exception: Hendrix et al. 1981). Furthermore, the ability of $O$. bimaculoides to grow rapidly and reproduce successfully at a temperature of $23^{\circ} \mathrm{C}$ suggests clearly that this species' geographic range could extend well south of its known southern limit on the upper Baja Peninsula (Forsythe and Hanlon 1988).

The strong growth and reproduction differences noted here, with a $5 \mathrm{C}^{\circ}$ temperature difference, underscore the important effects of natural temperature anomalies such as El Niño. Off California between eariy 1983 and late 1984, there was a mean temperature rise of about $3.5 \mathrm{C}^{\circ}$, with some short-term anomalies of up to $6 \mathrm{C}^{\circ}$ (McGowan, 1984). The temperature data from Santa Barbara reflect these increases (Fig. 5). In nature, the impact of major shifts in temperature on population dynamics and ecology is poorly understood, but would be expected to be greater on short-life-span predators such as Octopus spp. than on fishes that are iteroparous and longer-lived. The results of the present study combined with other published information (Forsythe and Hanlon 1988) would suggest the following effects of an El Niño event on field populations of $O$. bimaculoides: (1) the elevated temperature (up to $25^{\circ} \mathrm{C}$ ) would have no predictable detrimental effect on the biology of this species, (2) females near maturity would spawn weeks to months sooner, (3) embryonic development in existing egg broods would be accelerated, and (4) hatchlings and juveniles still in the exponential growth phase would undergo a period of accelerated growth (assuming sufficient food availability).

This last effect would probably produce the greatest local impact ecologically. Using the temperature data in Fig. 5 for Santa Barbara, Octopus bimaculoides hatching in July of a "normal" year (1982) would grow for 5 mo at an average temperature of $16^{\circ} \mathrm{C}$ compared to $18.6^{\circ} \mathrm{C}$ in an El Niño year (1983). This slight difference can have a dramatic effect in an organism capable of exponential growth. Assuming a growth rate from hatching of $3.0 \%$ at $16.1^{\circ} \mathrm{C}$ vs $3.6 \%$ at $18.6^{\circ} \mathrm{C}$, octopuses would be 2.5 times larger $(16.6 \mathrm{~g}$ vs $6.7 \mathrm{~g})$ after $5 \mathrm{mo}$ in an El Niño year. The increased growth rate is produced by an increase in feeding rate due to increasing temperatures (food conversion efficiency or gross growth-efficiency remain constant). As the octopus population grows in weight it will be consuming a relatively greater biomass of prey than would be consumed in a year with normal temperatures. Such increased growth might be expected to have a measurable impact on prey species of juvenile O. bimaculoides, especially since juvenile octopuses are known to have feeding rates on the order of 10 to $17 \%$ of their body weight per day (Forsythe 1984). Field data are needed to corroborate our laboratory results and to provide a baseline for ecological studies of this species.

Acknowledgements. We thank R. DeRusha, L. Bradford, S. Breslin and $\mathrm{C}$. Moates for their fine technical assistance in the laboratory culture work and J. Koppe for help with computer analyses. We thank S. Anderson for temperature data from Santa Barbara, and $R$. Ambrose and D. Manahan for reviewing the final draft. The typing and proofing of this manuscript by $\mathrm{L}$. Koppe is much appreciated. Funding from DHHS Grant RR 01279 and the Marine Medicine Account of The Marine Biomedical Institute is gratefully acknowledged.

\section{Literature cited}

Ambrose, R. F. (1984). Food preferences, prey availability, and the diet of Octopus bimaculatus Verrill. J. exp. mar. Biol. Ecol. 77: $29-44$

Ambrose, R. F. (1986). Effects of octopus predation on motile invertebrates in a rocky subtidal community. Mar. Ecol. Prog. Ser. 30: 261-273

Ambrose, R. F. (1988). Population dynamics of Octopus bimaculatus: influence of life history patterns, synchronous reproduction and recruitment. Malacologia 29 (1): 23-29

Boletzky, S. von (1974). The "larvae" of Cephalopoda: a review. Thalassia jugosl. 10: 45-76

Boyle, P. R. (ed.) (1983). Cephalopod life cycles, Vol. I. Species accounts. Academic Press, London

Boyle, P. R. (ed.) (1987). Cephalopod life cycles, Vol. II, Comparative reviews. Academic Press, London

Brody, S. (1945). Bioenergetics and growth with special reference to the efficiency complex in domestic animals. Hafner Press, New York

Brown, M. E. (1957). Experimental studies on growth. In: Brown, M. E. (ed.) The physiology of fishes, Vol, 1, Metabolism. Academic Press, New York, p. 361-400

DeRusha, R. H., Forsythe, J. W., Hanlon, R. T. (1988). Laboratory growth, reproduction and life span of the Pacific pygmy octopus, Octopus digueti. Pacif. Sci. 41: $51-59$

Dorsey, E. M. (1976). Natural history and social behavior of Octopus rubescens Berry. Master's thesis, University of Washington, Friday Harbor

Forsythe, J. W. (1984). Octopus joubini (Mollusca: Cephalopoda): a detailed study of growth through the full life cycle in a closed seawater system. J. Zool., Lond. 202: 393-417

Forsythe, J. W., Hanlon, R. T. (1988). Behavior, body patterning and reproductive biology of Octopus bimaculoides from California. Malacologia 29 (1): 40-56

Forsythe, J. W., Van Heukelem, W. F. (1987). Cephalopod growth. In: Boyle, P. R. (ed.) Cephalopod life cycles, Volume II, Comparative reviews. Academic Press, London, p. 135-155

Gould, S. J. (1966). Allometry and size in ontogeny and phylogeny. Biol. Rev. 41: 587-640

Guerra, A. (1979). Fitting a von Bertalanffy expression to Octopus vulgaris growth. Investigación pesq. 43: 319-329

Hanlon, R. T. (1983). Octopus briareus. In: Boyle, P. R. (ed.) Cephalopod life cycles, Vol. I. Species accounts. Academic Press, London, p. 251-266

Hanlon, R. T., Forsythe, J. W. (1985). Advances in the laboratory culture of octopuses for biomedical research. Lab. Anim. Sci. 35: $33-40$

Hartwick, B. (1983). Octopus dofleini. In: Boyle, P. R. (ed.) Cephalopod life cycles, Vol. 1, Species accounts. Academic Press, London, p. 277-291 
Hendrix, J. P., Jr., Hulet, W. H., Greenberg, M. J. (1981). Salinity tolerance and the responses to hypoosmotic stress of the bay squid Lolliguncula brevis, a euryhaline cephalopod mollusc. Comp. Biochem. Physiol. 69A: 641-648

Hochberg, F. G., Jr,, Fields, W. G. (1980). The squids and octopuses. In: Morris, R. H., Abbott, D. P., Haderlie, E. C. (eds.) Intertidal invertebrates of California, Chapter 17: Cephalopoda. Stanford, Stanford University Press, p. 429-444 and P133-P136

Mangold, K. (1983). Octopus vulgaris. In: Boyle, P. R. (ed.) Cephalopod life cycles, Vol. 1, Species accounts. Academic Press, London, p. 335-364

McGowan, J. A. (1984). The California El Niño, 1983. Oceanus 27(2): 48-51

Packard, A. (1972). Cephalopods and fish: the limits of convergence. Biol. Rev. 47: 241-307

Pascual, E. (1978). Crecimiento y alimentación de tres generaciónes de Sepia officinalis en cultivo. (Growth and feeding of three generations of lab-reared Sepia officinalis.) Investigación pesq. 42: 421-442

Pickford, G. E., McConnaughey, B. H. (1949). The Octopus bimaculatus problem: a study in sibling species. Bull. Bingham oceanogr. Coll. 12(4): 1-66
Richard, A. (1966). Action de la temperature sur l'evolution genitale de Sepia officinalis L. C. r. hebd. Séanc. Acad. Sci., Paris 263: 1998-2001

Ricker, W. E. (1979). Growth rates and models. Fish Physiol. 8: $677-743$

Van Heukelem, W. F. (1976). Growth, bioenergetics and life-span of Octopus cyanea and Octopus maya. Ph.D. dissertation, University of Hawaii, Honolulu

Van Heukelem, W. F. (1979). Environmental control of reproduction and life span in Octopus: an hypothesis. In: Stancyk, S. E. (ed.) Reproductive ecology of marine invertebrates. University of South Carolina Press, Columbia, p. 123-133

Wells, M. J., Wells, J. (1970). Observations on the feeding, growth rate and habits of newly settled Octopus cyanea. J. Zool., Lond. 161: 65-74

Young, R. E., Harman, R. F. (1988). "Larva," "paralarva" and "subadult" in cephalopod terminology. Malacologia 29 (1): 201-207

Zar, J. H. (1974). Biostatistical analysis. Prentice-Hall Inc., Englewood Cliffs

Date of final manuscript acceptance: February 22, 1988.

Communicated by R. S. Carney, Baton Rouge 